DOI: $10.25140 / 2411-5215-2018-2(14)-41-48$

\author{
Andriy Partola
}

\title{
RESEARCH ON FUNCTIONING CONDITIONS OF ENTERPRISES OF INLAND WATER TRANSPORT OF UKRAINE: PROBLEMS AND PROSPECTS
}

\author{
Андрій Партола \\ ДОСЛІДЖЕННЯ УМОВ ФУНКЦІОНУВАННЯ ПІДПРИЕМСТВ \\ ВНУТРІШНЬОГО ВОДНОГО ТРАНСПОРТУ УКРАЇНИ: ПРОБЛЕМИ \\ ТА ПЕРСПЕКТИВИ
}

\author{
Андрей Партола \\ ИССЛЕДОВАНИЕ УСЛОВИЙ ФУНКЦИОНИРОВАНИЯ ПРЕДПРИЯТИЙ \\ ВНУТРЕННЕГО ВОДНОГО ТРАНСПОРТА УКРАИНА: ПРОБЛЕМЫ \\ И ПЕРСПЕКТИВЫ
}

\begin{abstract}
The article is devoted to the study of operating conditions of Ukrainian water transport enterprises and the identification of barriers for its effective development. Classification of all problems by groups such as natural, technical, political and economic ones is carried out. Reasons of high cost of river traffic, low level of infrastructure and non-compliance of legislative base with modern requirements are analyzed. A comparison of approaches to solving the identified problems in Ukraine and EU countries is conducted. Strategic directions for the development of inland waterways enterprises of Ukraine in the conditions of European integration are outlined.

Keywords: river transport; European integration; freight transportation; charges for river traffic.

Fig.: 2. References: 13.

Стаття присвячена дослідженню умов функиіонування підприємств водного транспорту Украӥни та виявленню бар'єрів для його ефективного розвитку. Здійснено класифікаиію всіх проблем за такими групами, як природні, технічні, політичні та економічні. Проаналізовано причини високої собівартості річкових перевезень, низького рівня індраструктури та невідповідності законодавчої бази сучасним вимогам. Проведено порівняння підходів до вирішення виділених проблем в Україні та країнах СС. Окреслено стратегічні напрями розвитку підприємств внутрішніх водних перевезень України в умовах європейської інтеграиії.

Ключові слова: річковий транспорт; європейська інтеграція; вантажні перевезення; збори за річкові перевезення.

Рис.: 2. Бібл.: 13.

Статья посвящена исследованию условий функционирования предприятий водного транспорта Украины и выявлению барьеров для его эффективного развития. Осуществлена классификация проблем по таким группам: природные, технические, политические и экономические. Проанализированы причины высокой себестоимости речных перевозок, низкого уровня инфраструктуры и несоответствия законодательной базы современным требованиям. Проведено сравнение подходов к решению выделенных проблем в Украине и странах ЕС. Определены стратегические направления развития предприятий внутренних водных перевозок Украины в условиях европейской интеграции.

Ключевые слова: речной транспорт; европейская интеграция; грузовые перевозки; сборы за речные перевозки.

Рис.: 2. Библ.: 13.

JEL Classification: L10, L91
\end{abstract}

Target setting. Balanced development of the modern transport system of the country is impossible without the development of inland water transport. Support of this type of transport is given much attention in the EU, due to its positive impact on improving the environment and reducing the load on highways. The EU has adopted the Marco Polo II Program, the Naiades Action Plan and the Plan of the Platinum program implementation. As a result of their implementation by 2030 , road transport should refocus 30 percent of international and long-distance freight traffic, primarily on internal water transport, as well as rail transport in the EU. It is expected that by 2030 , the share of river transport in goods delivery within the EU will be $15 \%$. Taking into consideration Ukraine's orientation towards European integration, all of these trends will increase in the domestic economy. Therefore, there is an urgent need to study existing problems of the inland waterways industry in Ukraine and outline its promising areas of development.

Uninvestigated parts of general issue defining. To the analysis of economic development of water transport enterprises, a number of works by domestic authors is devoted, namely: Vernygora R., Bonyar S. M., Grytsenko S. P., Gurzhiy N., Okorokov A., Tsuprov and others. In their studies, problems of development of domestic inland water transport are clarified and mechanisms and models of its effective reforming are proposed. Partly the study of river transport was carried out in the framework of scientific works devoted to identification of interconnections between different types of transport and mechanisms development for their

(C) Партола А. I., 2018 
effecient mutual functioning. The most famous researchers of this area are Grytsyik Ye., Voloshenko A., Sadlovska I., Martsenyuk L. However, the issue of further development of inland water transport enterprises remains relevant, especially given existing problems of their functioning and prospects of integration into the European transport system.

Purpose of the article. In connection with the above, the purpose of the study is to identify, analyze and classify the problems of functioning of inland water transport enterprises of Ukraine and outlining strategic directions of its development in the conditions of European integration.

Statement of the main material. Research of economic conditions of enterprises functioning of inland water transport of Ukraine showed, that overwhelming majority of them constantly meet with a number of problems and restrictions, which have a negative impact on economic outcomes. The whole continuum of reasons, which causes them, can be conditionally divided into three blocks - these are natural problems; problems of economic nature and legislative-regulatory nature.

Among the problems, which constrain inland transport development, natural constraints have the least significant negative impact. Unfavorable natural conditions of enterprises operation of inland water transport include: 1) availability of winter break in navigation (1,5-4 months); 2) a significant fluctuation in water state, in particular, in summer in steppe strip; 3) frequent river turns and silting (especially in forest and black earth zone);4) shallowness of estuaries; 5) a small number of rivers in the same direction; 6) presence of rapids on the main river artery - the river Dipro.

However, not listed factors are the main reasons for low competitiveness of river transport in Ukraine. The problem lies primarily in high cost of river transport, which, for example, by grain transportation are $30 \%$ higher than in the EU and $40 \%$ higher than in the USA [1].

The reason for this situation is that the total cost of transportation, except for direct material and operational costs, includes a number of mandatory payments and fees, which should by paid by enterprises of river transport. So, today, a carrier for goods transportation by river must pay:

- canal toll;

- drawbridge fee;

- pilotage fee;

- tonnage tax and port-duty;

- gateway charges;

- payment for water use;

- various one-time permissions.

The total amount of these fees depends on the type and size of the vessel and is about 1.9-2.0 USD per ton of cargo. Pilotage fee and port-duty fees make even more expensive tons of cargo for 4.0-4.5 USD. The most expedient part is obtaining one-time permits, depending on the type and ownership of the vessel; they can make 300-500 USD [2].

Most representatives of business and experts consider a problem to be a mandatory monopoly pilotage fee. Pilotage feep - it is the duty of the captain established by the state to take on board a pilot from a state enterprise, which gives «recommendations» to the ship driver. It can make up to $\$ 20$ thousand per run or up to $\$ 7$ per ton for a vessel with a capacity of up to 3 thousand tons.

According to the calculations made by LLC «Hermes-Trading», when transporting cereals, additional charges, including pilotage fee, make up almost $60 \%$ of the freight cost. If additional charges are cancelled, the cost of transportation may decrease to $\$ 10-12$ per ton, which will allow competing with transportation by rail [3].

In addition, the negative impact on the river transport development is affected by the imbalance between the fees rates for coastal and overseas voyages, which reduces the interest in sending small consignments (up to 6-7 thousand tons per vessel) for immediate export. At present, it is extremely important to reduce the difference in the fees rates for coastal and overseas voyages. Similar changes in regulatory policy could contribute to increasing overseas transportations and, therefore, stimulate the export of agricultural products by river routes at the cost of lowering the primary cost and expenditures on of logistics. 
As a result, transport by inland water transport costs more than transportation by rail or motor transport. Under such conditions, it is more profitable to carry, mainly bulk cargo: scrap metal, ore, sand and other raw materials.

Consequently, unreasonably high levels of fees, their number and compulsory nature (e.g., pilotage fee) create unfavorable conditions for expanding existing carriers and make inappropriate the emergence of new inland waterways.

In Europe, when shipping goods by water transport, ship-owners do not pay to the budget, and the towed fleet is not subject to excise duty. If in the USA the excise duty is 70 dollars / ton, then in Ukraine - 139 euros / $\mathrm{t}$. Argumentation of port duties is also debatable. For example, only for the run from Mykolaiv to Ochakiv (44 nautical miles), the cost for services paying is about 4.85 dollars / t. [4; 5]. According to experts from the World Bank, the economically justified amount of port duties in Mykolaiv should not exceed 1.85 dollars. In economically developed countries of the world, it has long been realized that only by developing river transport it is possible to remove loads from highways and thus save on road repairs. Therefore, while by river transport in Ukraine only $0.2 \%$ of the total volume of domestic freight traffic is transported, as opposed to European countries, where this indicator is significantly higher (Fig. 1).

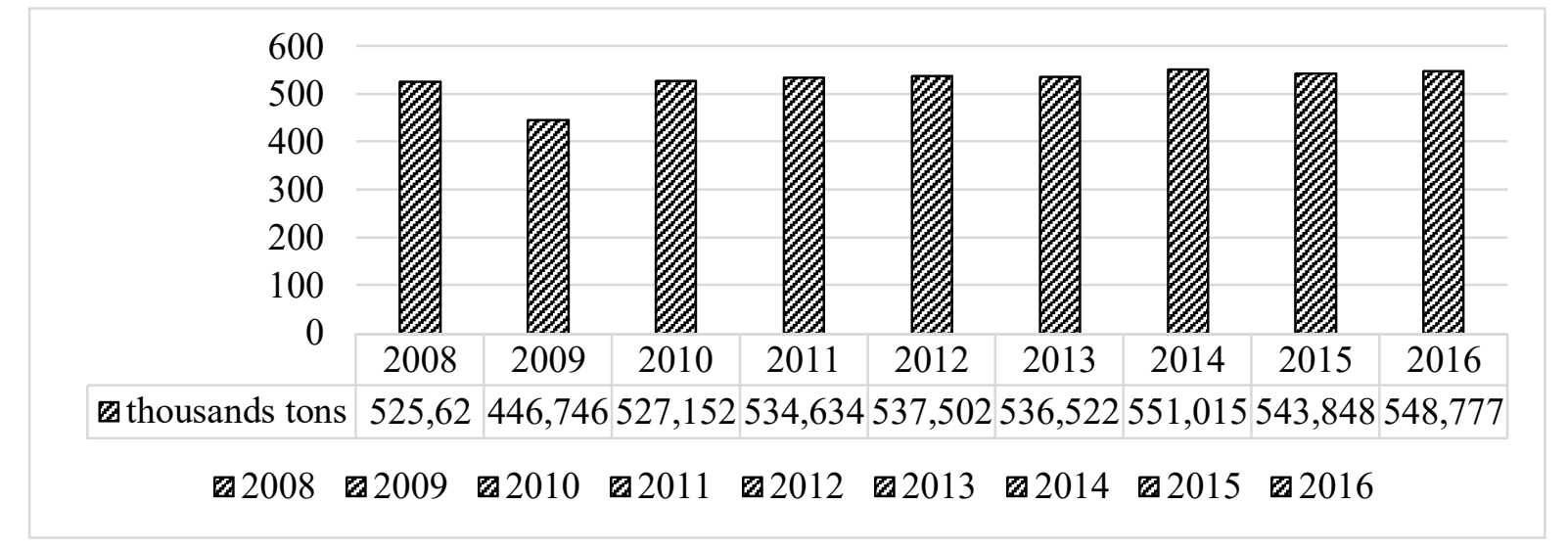

Fig. 1. Dynamics of freight traffic by inland water transport in the EU countries

Source: [6].

for the period of 2008-2016 (thousands tons)

As a result of the situation described above, in the domestic river transport, there is almost a complete replacement of freight flows by rail and road transport. This imbalance is also aided by low railway tariffs and the lack of control over allowable loads for road freight transport. The consequence is a chronic problem with the state of roads, the wear of a railroad fleet, the constant need for state subsidies, and the loss of river transport capacity as cheaper and more environmentally friendly. In addition, it should be noted that with the use of road transport, despite its convenience and possibility of small consignments transportation, high cost of transportation is also a significant disadvantage. Regarding railway logistics, it also has a number of problems, in particular rolling stock shortage, its unsatisfactory technical condition, gradual increase of tariffs. All this negatively affects the activities of business entities, making untimely or disadvantageous fulfillment of the obligations undertaken to deliver products under foreign economic agreements and agreements with domestic businesspersons. Therefore, there is a need to find alternative ways of transportation.

Thus, reorientation from road and rail transport to the river transport today is one of the most important tasks for the transport industry of Ukraine. As European and world practice shows, such goods as grain, sand, stone, ore, containers, etc., are much more profitable to transport along the river. In the United States, for example, there are active transports by Mississippi, in the EU; the rivers that are actively used are Rhine and Danube. 
An important problem hampering the development of river transport in Ukraine is an outdated material and technical base, low level of mechanization of transshipment operations, considerable physical and moral depreciation of river vessels, and small share of packed goods in total. Almost all Ukrainian river transport is subsidiary and focuses on large batches of goods, mainly construction materials, grain, etc. These factors adversely affect the competitiveness of inland water transport.

The number of technically and morally obsolete vessels is about $81.9 \%$. As part of the fleet, the largest share of outdated vehicles is cargo and passenger $(97.1 \%)$, cargo bulk $(89.5 \%)$, bulk carrier $(84.4 \%$ ) [7]. River-sea transport vessels, which today are considered most effective for cargo transportation, mainly belong to the well-known shipping companies: ASK "Ukrrichflot"; PJSC «Ukrainian Danube shipping company» (PJSC «UDSC»), which has the status of a national carrier; KDM Shipping Public Ltd (Cyprus) - the holding company of the shipping operator «Metropolitan Shipping Company» Ltd. (Kyiv), which carries out cargo and passenger transportation in domestic direction and abroad, which are the main types of their activities, as well as LLC JSC «NIBULON», which carries out transportation of agricultural goods by own company's vessels (coastal and international transportations). In 2012, the company exported more than $10 \%$ of Ukrainian grain, carrying out transportation in the amount of 3.5 million tons [8].

In order for the rivers to be navigable, it is necessary to do a deeping of bed. For more than last twenty-five years, the length of shipping routes has decreased from $4005 \mathrm{~km}$ to 1600 $\mathrm{km}$ due to gradual silting and rubbing. The river Desna has ceased to be used for shipping traffic. Necessary depths between Pripyat and Dnieper are not supported. Southern Bug in Mykolaiv region washed with a depth of 2.9 meters to 1.65 meters. The biggest problem for carriage is a ride near Kamyanske on the Dnipro River due to the presence of underwater rocks between the cities of Kamyanske and Dnipro. For the period of 1990-2016, the length of the river navigable public transport routes decreased by 1.9 times. In recent years, the quality of roads has started to improve somewhat because of dredging works on Dnipro, Southern Bug and Danube. Financing of works was carried out at the expense of LLC JSC «NIBULON». Dredging works carried out in 2009 in the Danube Delta led to an increase for $47 \%$ of ships passage [1]. Despite certain positive trends, as described above, the need for intensification of dredging works remains.

There are problems in organizing logistics for water transportation. The vast majority of infrastructure facilities, including 12 ports, are abandoned and obsolete. The problem is the use of gateways because they are in critical condition because of significant wear and tear. Some of the locks are already almost 70 years old. Specialists warn that if you leave them in the current state, then there is a high probability of an industrial disaster. A similar situation is with the river ports that were built during the Soviet period. The structure of most ports and stations does not meet international standards, and their capacity is used only by $10 \%$.

Despite the abandoned state of the river infrastructure of Ukraine, however, internal waterways can potentially become transport arteries for transportation, primarily agricultural products and construction materials. Taking into consideration the cost of logistics services and routes that are available, new opportunities for transportation of agricultural products are opened.

It should be noted that Ukraine has an opportunity to enter Rhine-Main-Danube navigable canals and deliver goods by inland water transport practically throughout Europe through an extensive system of inland waterways and mouth ports of Amsterdam, Rotterdam, Antwerp, Constanta. In addition, for Ukraine, waters of Oder-Vistula-Pripyat-Dnipro and Western Dvina-Pripyat-Dnipro are promising. Crossing Poland, Belarus and Ukraine, the E-40 waterway connects the ports of Gdansk and Kherson. However, at present the land between Warsaw and Brest is not suitable for shipping traffic.

In November 2015, representatives of the Ministry of Infrastructure of Ukraine participated in the 2nd session of the Commission on the development of the E-40 water transport con- 
nection at the Dnipro-Vistla site. Restoration of river trade will increase annual turnover up to 4 million tons, as well as create logistic centers from which cargo will be able to go to Europe and Asia. A similar perspective is extremely relevant for Ukraine, which has lost a number of markets over the past two years. Studies have shown that, given state assistance and attraction of sufficient investments, the specified trunk may become an alternative to existing transport routes, which will promote the development of competition in the transport market, increase the level of transport of shippers, in particular domestic agricultural producers, and the diversification of risks at the transportation stage.

Odessa region is also promising for revitalization of river shipping. It has a number of advantages:

- within Odessa region there are several major rivers where shipping is carried out;

- the region has the most attractive part of the Danube River, which connects Ukraine with the EU member states in Central and Western Europe, as well as with the Balkans;

- Isakcha-Orlovka ferry service is being built, which is extremely important foe successful shipping.

Legal basis for cooperation in the field of ferry transport between Ukraine and Romania was signed in 2014, when the Cabinet of Ministers of Ukraine adopted the Order «On approval of the Agreement (in the form of an exchange of notes) between the Cabinet of Ministers of Ukraine and the Government of Romania on the opening of an international border crossing point through the Ukrainian-Romanian state border for ferry, passenger and freight connections between the settlements Orlovka (Ukraine) - Isakcha (Romania)» [9].

Specialists believe that the formation of this transport corridor will increase the annual capacity of up to 200 thousand cars, 50 thousand trucks and tourist buses. In case of successful completion of the ferry service construction between Ukraine and Romania, savings over time will be 10-12 hours, and in length - $200 \mathrm{~km}$ of run [10].

All of these areas can be developed in close partnership with EU member states as well as with financial and advisory assistance from EU leaders.

At present, Ukraine has virtually no legislative framework regulating annual transportation and port infrastructure operations. The only modern legal act at the level of law, regulating the functioning of river ports, is the Law of Ukraine «On Transport». In this sphere, the «Charter of inland water transport of the USSR» of 1963 and some modern by-laws [11] are still used.

There is a separate block of problems concerning the movement of inland waterways of vessels under foreign flags. In order for a foreign vessel to be able to navigate inland waterways of Ukraine, the owner of a vessel must obtain a one-time temporary permit if there are no international shipping agreements between Ukraine and the country of origin of the vessel. Some fees for such vessels must be paid at special fares higher than those for a Ukrainian flag vessel.

In the opinion of most specialists, the main obstacle to the development of river navigation in Ukraine is the mismatch of legislative framework to modern requirements. Currently, legislation regulating inland water transport has been in place since 1961. Attempts to create new ones have been made over the last 10 years. In particular, a draft law 2475a «On Inland Water Transport» was developed, which was received by the Verkhovna Rada in August 2015 , but is still pending. This draft law is based on the best practices and legislation of the European Union. Based on the experience of European countries, the bill is based on the principle of maximum simplicity of the system of goods and passengers transportation.

Draft law 2475a offers a new way of pricing tariffs and opening access to inland waterways. It proposes a new approach to the calculation of payments, for example, it is expected to cancel almost all tariff and non-tariff restrictions and the introduction of one collection - a river one, which will depend on the number of goods, passengers and distance. If the law comes into force, cargo owners will be able to save on each ton of cargo $\$ 1.5-2.5$. However, 
specialists warn that the principle of the river tax formation is not clearly set out in the draft law, which may become an occasion for manipulation in the future.

In addition to the draft law 2475a, it is planned to cancel single permits for use of inland waters of Ukraine. Restrictions that are now in force oblige foreign companies, in addition to paying higher tariffs, to receive permits too. This situation creates barriers for attracting investments in inland water transport and leads to monopolization of the river transport market. The lack of a competitive environment causes over-pricing of transportation and growth of cost.

Creating and adopting well-thought-out legislation, that would take into account interests of all market participants, would undoubtedly contribute to the development of river infrastructure and reduce the cost price, primarily of agricultural products, which is an important export product of Ukraine. Improvement of the legislation would also create favorable conditions for unloading the railway and reducing the load on the roads. The project of creating a water corridor connecting the Baltic Sea and the Black Sea, which would change the role of river transport from the auxiliary to the business-oriented, may also, be economically promising.

Signing the Association Agreement between Ukraine and the European Union creates certain prospects for the development of inland water transport, as it promotes the introduction of improved standards of work in this field. In the context of the revival of the river transport of Ukraine, development of the strategy on inland waterways improvement becomes of particular importance. The tasks aimed at the below mentioned spheres should be of priority:

- development and renewal of port infrastructure;

- revival of navigation on other rivers, including small ones;

- connection to the external routes of the river connection, in particular to the water route $\mathrm{E}-40$;

- implementation of the European Union standards in the field of inland waterways;

- development of shipbuilding in Ukraine;

- mechanisms introduction for stable functioning of the water transport infrastructure;

- development of transparent mechanisms on activities regulation in this sphere.

As noted above, prospects for the development of inland water transport are partly related to the implementation of European norms and standards in the field of river transport. The main achievements of the process of European integration in the researched sphere in the recent period are norm approximation of the Ukrainian legislation to the European ones and the formation of corresponding organizational structures.

To implement the latter, the task of the Ministry of Infrastructure of Ukraine is to direct its efforts in order to create a new organizational-legal and economic model of inland water transport management, which would contribute to supporting the competitive environment in the river transport market, on account of the emergence of new economic entities of various forms of ownership of both domestic and foreign origin, increase of investment attractiveness of the industry and formation of new organizational forms of cooperation, such as cluster of enterprises $[12 ; 13]$.

In order to revive and further develop the navigable potential of Ukrainian rivers, it is necessary to take a number of measures aimed at eliminating some of the most important problems presented in Fig. 2.

Each of these problems that affect the development of river transport in Ukraine requires careful study and decision-making at the state level. Particular attention should be paid to the development and adoption of a legislative framework regulating river transport, as well as the creation of favorable economic and political conditions for attracting investments in river transport development. 
ГАЛУЗЕВИЙ АСПЕКТ РОЗВИТКУ НАЦІОНАЛЬНОГО ГОСПОДАРСТВА

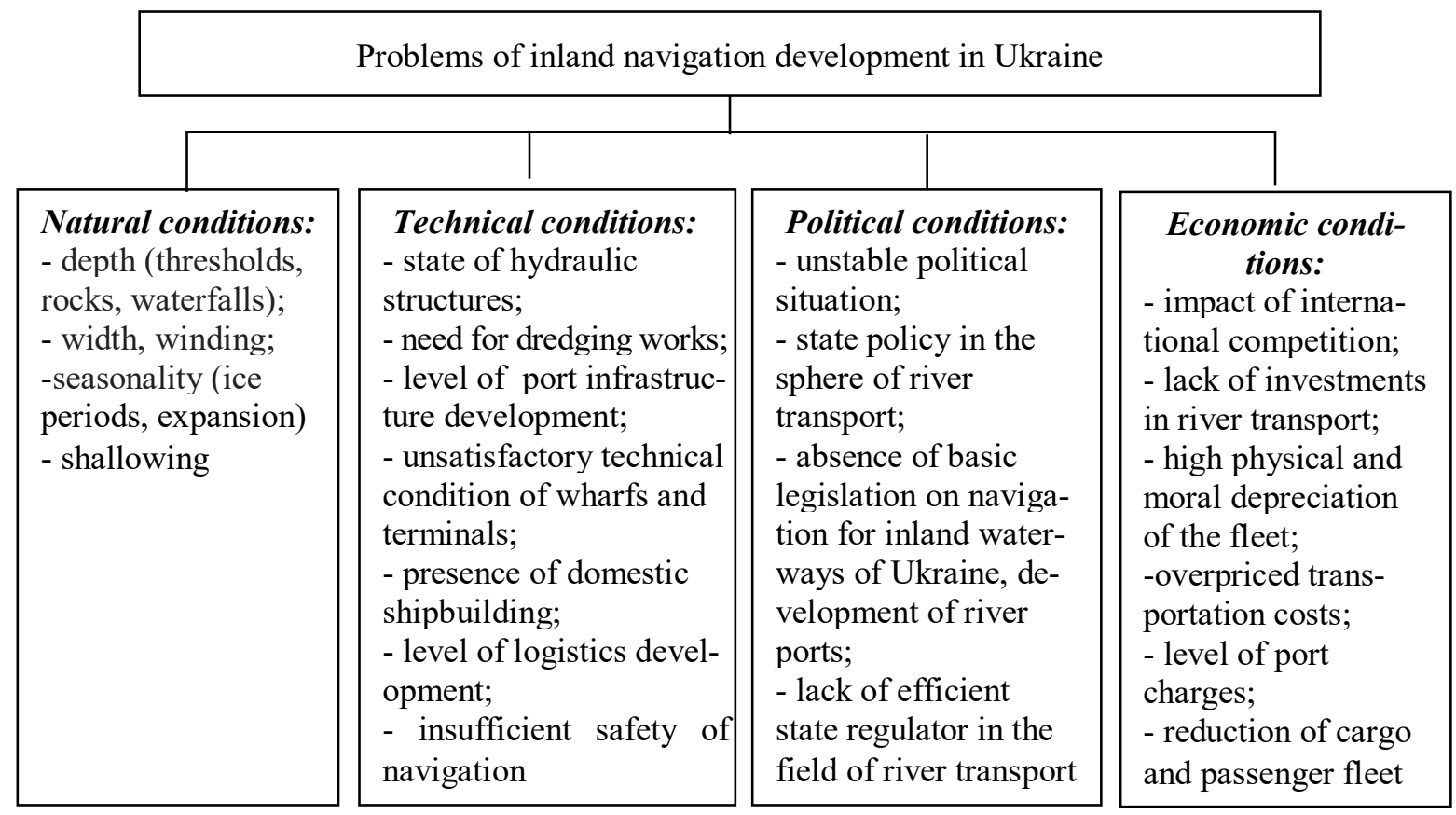

Fig. 2. Overall structure of the problems of inland navigation development in Ukraine

Conclusions. Ukraine has a large and unrealized potential for inland waterway transport. The most promising regions for the development of river navigation are traditionally two largest rivers - the Dnipro river and the Danube river. Infrastructure development and river fleet renewal, adoption of a number of legislative initiatives, aimed at simplifying the work of river carriers, can become an additional factor of activating economic activity in Ukraine. Taking into consideration prospects of river communication in the western direction, the implementation of infrastructure projects concerning the partnership of Ukraine and the EU member states is relevant.

The above shows, despite the existence of a number of barriers, there are quite significant prospects for the development of river transport in Ukraine. The practice of economically developed countries shows that development of international transport corridors, modernization of infrastructure, and construction of transport and logistics centers at river ports etc., develop most efficiently, if network approaches are applied to transport management, in particular clusters of enterprises.

\section{References}

1. Rezvoliutsiia na vode: kak Ukraine zarabotat na rekakh /Revolution on water: how to make money on rivers in Ukraine]. Retrieved from https://www.segodnya.ua/economics/transport/ revolyuciya-na-vode-kak-ukraine-zarabotat-na-rekah-1136749.html.

2. Ministerstvo infrastruktury Ukrainy: ofitsiinyi sait [Ministry of Infrastructure of Ukraine: official site]. URL: http://mtu.gov.ua.

3. Vid Horishnikh Plavniv i dali. Stan richkovoho transportu v Ukraini /From Horishni Plavni and further ahead. State of river transport in Ukraine7. Retrieved from http://zerkalo.mk.ua/novini/ vid-gorishnix-plavniv-i-dali-stan-richkovogo-transportu-v-ukra\%D1\%97ni.html.

4. Sledz, S. (December 1, 2017). Ukraina ne potrebuie koruptsiinykh zakoniv dlia vidrodzhennia richkovoho [Ukraine does not need corrupt laws to revive the river]. Dzerkalo tyzhnia-Mirror of the week [in Ukrainian].

5. Ivanov, S. V. (2018). Transportno-lohistychni klastery v konteksti rozvytku transportnoi systemy Ukrainy ta okremo vziatoho ekonomichnoho raionu 「Transport-logistic clusters in the context of the transport system development of Ukraine and a separate economic region]. Ekonomichnyi visnyk Donbasu - Economic Bulletin of Donbass, 1 (51), 15-22 [in Ukrainian].

6. Eurostat. Retrieved from https://ec.europa.eu/eurostat.

7. Karmazina, O. O. (Ed.). Transport i zviazok Ukrainy. 2016 [Transport and communications of Ukraine. 20167 (2017). Kyiv: Derzhavna sluzhba statystyky Ukrainy [in Ukrainian].

8. Nibulon. Retrieved from http//forbes.ua/company/709.

9. Pro skhvalennia Uhody (u formi obminu notamy) mizh Kabinetom Ministriv Ukrainy i Uriadom Rumunii pro vidkryttia mizhnarodnoho punktu propusku cherez ukrainsko-rumunskyi derzhavnyi kordon 


\section{ГАЛУЗЕВИЙ АСПЕКТ РОЗВИТКУ НАЦІОНАЛЬНОГО ГОСПОДАРСТВА}

dlia poromnoho, pasazhyrskoho ta vantazhnoho spoluchennia mizh naselenymy punktamy Orlivka (Ukraina) - Isakcha (Rumuniia) 「On approval of the Agreement (in the form of the exchange of notes) between the Cabinet of Ministers of Ukraine and the Government of Romania on the opening of an international border crossing point through the Ukrainian-Romanian state border for ferry, passenger and freight connections between the settlements Orlivka (Ukraine) - Isakcha (Romania)]. № 1129-r (dated November 19, 2014). Retrieved from: https:/www.kmu.gov.ua/ua/npas/247770784.

10. Poromnu perepravu mizh Ukrainoiu i Rumuniieiu planuiut vidkryty u veresni [The ferry crossings between Ukraine and Romania are scheduled to open in September7. Retrieved from https://zik.ua/news/2018/04/26/poromnu_perepravu_mizh_ukrainoyu_i_rumuniieyu_planuyut_vidkryt y_u_veresni 1313285 .

11. Pro transport 「About transport]. № 232/94-VR (10.11.1994). Retrieved from zakon.rada.gov.ua/go/232/94-vr.

12. Palyvoda, O. M., Plavan, V. P. (2016). Otsiniuvannia synerhetychnoho efektu formuvannia klasternykh orhanizatsiinykh struktur 「Evaluation of the synergetic effect of forming cluster organizational structures]. Ekonomichnyi chasopys-XXI - Economic Newsletter-XXI, 158 (3-4(2)), 48-51 [in Ukrainian].

13. Palyvoda, O. M. (2016). Pidkhody do formuvannia klasternoi infrastruktury v krainakh Yevropeiskoho Soiuzu 「Approaches to the formation of cluster infrastructure in countries of the European Union]. Vodnyi transport - Water transport, 2 (25), 109-115 [in Ukrainian].

\section{References (in language original)}

1. Революция на воде: как Украине заработать на реках. URL: https:/www.segodnya.ua/ economics/transport/revolyuciya-na-vode-kak-ukraine-zarabotat-na-rekah-1136749.html.

2. Міністерство інфраструктури України: офіційний сайт. URL: http://mtu.gov.ua.

3. Від Горішніх Плавнів i далі. Стан річкового транспорту в Україні. URL: http://zerkalo.mk.ua/novini/vid-gorishnix-plavniv-i-dali-stan-richkovogo-transportu-v-ukra\%D1\%97ni.html.

4. Следзь С. Україна не потребує корупційних законів для відродження річкового. Дзеркало тижня. 2017. 1 грудня.

5. Іванов С. В. Транспортно-логістичні кластери в контексті розвитку транспортної системи України та окремо взятого економічного району. Економічний вісник Донбасу. 2018. № 1 (51). C. 15-22.

6. Eurostat. URL: https://ec.europa.eu/eurostat.

7. Транспорт і зв'язок України. 2016 / відп. за вип. О. О. Кармазіна. Київ: Державна служба статистики України, 2017. 175 с.

8. Нибулон. URL: http//forbes.ua/company/709.

9. Про схвалення Угоди (у формі обміну нотами) між Кабінетом Міністрів України і Урядом Румунії про відкриття міжнародного пункту пропуску через українсько-румунський державний кордон для поромного, пасажирського та вантажного сполучення між населеними пунктами Орлівка (Україна) - Ісакча (Румунія): Розпорядження Кабінету Міністрів України від 19 листопада 2014 р. № 1129-p. URL: https://www.kmu.gov.ua/ua/npas/247770784.

10. Поромну переправу між Україною і Румунією планують відкрити у вересні. URL: https://zik.ua/news/2018/04/26/poromnu_perepravu_mizh_ukrainoyu_i_rumuniieyu_planuyut_vidkryt y_u_veresni_1313285.

11. Про транспорт: Закон України від 10.11.1994 № 232/94-ВР (зі змінами та доповненнями від 23 грудня 2015 року № 901-VIII). URL: zakon.rada.gov.ua/go/232/94-вр.

12. Паливода О. М., Плаван В. П. Оцінювання синергетичного ефекту формування кластерних організаційних структур. Економічний часопис-XXI. 2016. № 158 (3-4(2)). С. 48-51.

13. Паливода О. М. Підходи до формування кластерної інфраструктури в країнах Свропейського Союзу. Водний транспорт: зб. наук. праць. 2016. Вип. 2 (25). С. 109-115.

Partola Andriy - PhD student of the Department of Business Logistics and Transport Technologies, State University of Infrastructure and Technologies (19 Ivan Ogienko Str., 02000 Kyiv, Ukraine).

Партола Андрій Ігорович - аспірант кафедри бізнес-логістики та транспортних технологій, Державний університет інфраструктури та технологій (вул. Івана Огієнка, 19, м. Київ, 02000, Україна).

Партола Андрей Игоревич - аспирант кафедры бизнес-логистики и транспортных технологий, Государ-

ственный университет инфраструктуры и технологий (ул. Ивана Огиенко, 19, г. Киев, 02000, Украина).

E-mail: topcar@aet.ua

Partola, A. (2018). Research on functioning conditions of enterprises of inland water transport of Ukraine: problems and prospects. Problems and prospects of economics and management, 2 (14), 41-48. 